\title{
ОСОБЛИВОСТІ ПРОФЕСІЙНОЇ МОТИВАЦЇ̈ В ПРОЦЕСІ СТАНОВЛЕННЯ ПРОФЕСІЙНОЇ ІДЕНТИЧНОСТІ СТУДЕНТІВ СПЕЦІАЛЬНОСТІ «СОЦІАЛЬНА РОБОТА»
}

\author{
Людмила Новик \\ кандидат психологічних наук, доцент кафедри креативних індустрій та \\ соціальних інновацій \\ Національний університет «Чернігівська політехніка» \\ 14037, Україна, м. Чернігів, вул. Козацька, буд. 1-а \\ lyudmilanovik2015@gmail.com, https://orcid.org/0000-0001-9585-1673
}

\author{
Тамара Мазур \\ кандидат психологічних наук, доцент кафедри філософії і суспільних наук \\ Національний університет «Чернігівська політехніка» \\ 14037, Україна, м. Чернігів, вул. Козацька, буд. 1-а \\ offerlund@gmail.com, http://orcid.org/0000-0002-0609-6416
}

\begin{abstract}
Анотація
В статті розглядається проблема формування професійної ідентичності майбутнього фахівця соціальної роботи, яка на думку авторів, здатна суттєво підвищити вмотивованість студентства до набуття професії. Наводяться дані дослідження навчальної мотивації, які засвідчують прямий вплив рівня вищої освіти на специфіку професійної ідентичності випускників спеціальності «Соціальна робота». Динаміка становлення професійної ідентифікації у майбутніх соціальних працівників великою мірою обумовлюється їх особистісним розвитком. В студентів-магістрів більш яскраво, порівняно з випускникамибакалаврами, виявляється навчально-професійна ідентифікація, а випускники-бакалаври характеризуються переважанням внутрішньої мотивації професійної діяльності. Метою дослідження $\epsilon$ вивчення і формування професійної ідентичності майбутніх соціальних працівників у процесі вишівської підготовки, що ініціює пошук нових орієнтирів освіти, цілей, можливостей. В контексті поставленої проблеми нами поставлено завдання дослідити вплив освітнього контексту на динаміку становлення мотиваційних і ціннісно-смислових детермінант формування професійної ідентичності майбутніх фахівців соціальної роботи. Отримані результати доводять, що рівень вищої освіти впливає на специфіку професійної ідентичності випускників. На першому курсі у студентів, зазвичай, відбувається осмислення професійної ідентичності, коли на основі входження в нове соціальне і професійне середовище зовнішня студентська ідентичність переходить у внутрішньо прийняту, усвідомлену, емоційно забарвлену характеристику. У випускників-бакалаврів і магістрів відбувається формуванням нових цілей і перспектив професійного розвитку, переосмислення й уточнення різних варіантів професійно-творчого саморозвитку, працевлаштування та побудови професійної кар'єри. Тому підвищення конкурентоспроможності і мобільності майбутніх фахівців соціальної роботи зумовлює необхідність цілеспрямованого підвищення рівня професійної ідентичності студентів в період вишівської підготовки.
\end{abstract}


Ключові слова: професійна ідентичність, професійна мотивація, самореалізація, самовизначення, професійний розвиток, ідентичність.

\section{Вступ}

На цей час у теорії та практиці вищої освіти велика увага надається проблемі набуття самоідентифікації студентів із майбутньою професією, що пов’язано, насамперед, із впровадженням в освіту компетентнісного підходу, який передбачає здатність випускника добре і швидко орієнтуватися в мінливих умовах і приймати самостійні рішення, згодом нести за них відповідальність. Одним із основних критеріїв професійної компетентності майбутніх спеціалістів є рівень розвитку професійної ідентичності, в якій відображається прийняття чи неприйняття обраної професійної діяльності як засобу самореалізації та розвитку, налаштованість до професійного розвитку. Отже, вивчення професійної ідентичності в студентів соціальної роботи дозволить вирішити професійні проблеми, пов'язані із здійсненням практичної діяльності. Саме тому проблема формування професійної ідентичності є наразі досить актуальною.

Професійне становлення супроводжується зміною уявлень людини про себе, свого місця в професійному світі, професійним самовизначенням особистості, тобто набуттям професійної ідентичності. Формування професійної ідентичності особливого значення набуває у підготовці майбутнього соціального працівника, оскільки сама його особистість $є$ «інструментом» впливу на клієнта, а, отже, несформована професійна ідентичність гальмує становлення особистості соціального працівника як професіонала i, тим самим, унеможливлює його здатність до надання належної професійної допомоги. Вивчення i формування професійної ідентичності майбутніх соціальних працівників у процесі вишівської підготовки ініціює пошук нових орієнтирів освіти, цілей, можливостей. Професійна ідентичність $є$ набором певних характеристик, які допомагають людині орієнтуватися у світі професій, реалізовувати особистий професійний потенціал. Крім того, сформована професійна ідентичність підвищує рівень впевненості в собі, дозволяє відчувати причетність до великої професійної групи, визначити своє місце в світі соціальних взаємодій.

На цей час більшість дослідників збігаються в думці, що сформована професійна ідентичність забезпечує людині цілісність, визначеність і починає активно формуватися вже на етапі професійного навчання у просторі процесів самовизначення, самоорганізації, персоналізації. Тобто професійна ідентичність не може розглядатися окремо від особистісного розвитку, зокрема без урахування мотиваційної спрямованості (Н. Кривоконь, Л. Новик, Т. Мазур, В. Павлюх, Л. Шнейдер та ін.).

Як слушно зазначає А. Борисюк, формування професійної ідентичності, готовності до майбутньої професійної діяльності, знаходження професійного поля для самореалізації, підтримка у пошуку сенсу майбутньої професії, набуває особливого значення на завершальному етапі професійної освіти. Підкреслюючи значення цього феномена, авторка наголошує, що професійна ідентичність «допомагає особистості свідомо керувати своїм професійним становленням, свідомо обирати особистісно-цінну лінію свого професійного розвитку, надає цілісність і системність, передбачає упорядкування та інтеграцію потреб і професійних прагнень особистості, виникнення стійкої дієвої мотиваційної сфери, адекватне ставлення до себе як до професіонала, до професії, до представників професійної спільноти, запобігає професійному вигоранню» (Борисюк, 2010: 96). 
В психології склалися підходи, згідно яких професійна ідентичність, розглядається як складний інтегративний психологічний феномен (Азбель, 2004), як провідна характеристика професійного розвитку людини, що свідчить про ступінь прийняття обраної професійної діяльності як засіб самореалізації і розвитку» (Кривоконь, 2002). Крім того, це уявлення супроводжується певними ціннісними і мотиваційними орієнтирами, а також суб'єктивним ставленням (прийняттям чи ні) своєї професійної приналежності (Борисюк, 2010).

Розглядаючи структуру професійної ідентичності, вчені описали такі їі особливості. Професійна ідентичність розглядається як динамічна структура, яка об’єднує особистісну і соціальну форми ідентичності. Вона складається з когнітивного, емоційного і мотиваційноціннісного компонентів, зміст яких змінюється в процесі професійного розвитку особистості. Такі автори, як О. Єрмолаєва (Ермолаева, 1998), Е. Зеєр (Зеер, 1997), Л. Шнейдер (Шнейдер, 2004), у структурі професійної ідентичності виокремлюють когнітивний, емоційно-оцінний і мотиваційно-ціннісний компоненти. Когнітивний компонент розглядається як результат самопізнання і розуміння себе як професіонала. Емоційний компонент - це самоставлення, що містить самооцінку своєї професійної діяльності. Мотиваційно-ціннісний розглядається як процес самореалізації, постановка навчально-професійних цілей і планів, професійні установки і очікування від професійної діяльності.

Процес формування професійної ідентичності автори розглядають з різних аспектів.

Зокрема Е. Еріксон (Ericson, 1960) розглядав професійну ідентичність як процес, що пов'язаний із професійним самовизначенням, професійною самооцінкою, професійною спрямованістю, і містить задоволеність професією й професійною діяльністю, як компонент особистісної ідентичності, забезпечуючи успішний професійний розвиток.

О. Срмолаєва вважає, що професійна ідентичність - продукт тривалого особистісного і професійного розвитку, який стає сформованим тільки на досить високих рівнях оволодіння професією і виступає як стійке узгодження основних елементів професійного процесу, а саме, узгодження реальних і ідеальних професійних образів «Я». Це психосоціальна структура, в якій фокусуються основні стосунки професіонала в системі «людина-професіясуспільство» (Ермолаева, 1998).

Н. Кривоконь розглядає становлення ідентичності у професійній сфері через «активність», яка виступає багатовимірною категорією, що розкриває індивідуальноособистісний рівень здійснення діяльності, спілкування, пізнання (Кривоконь, 2002).

Водночас О. Срмолаєва вважає, що професійна ідентичність є аналогом понять професійного самовизначення, професіоналізації, професійного саморозвитку і т. ін. При цьому, автор підкреслює, що процес формування професійної ідентичності займає досить тривалий час і вимагає від особистості певного досвіду професійної діяльності. Це означає, що в процесі вишівської підготовки майбутній спеціаліст лише вступає в початок процесу професійної ідентичності, завершуючи його після закінчення вищої школи і лише за умови трудової діяльності за обраною професією. Однак $є$ вагомі підстави вважати, що цей процес може бути прискорений, якщо в процесі професійного навчання формуванню професійної ідентичності буде надаватися особлива увага. Тому професійна компетентність передбачає не лише теоретичне навчання, а й певний досвід практичної діяльності як в реальності, так i при проведенні ділових та імітаційних ігор, майстер-класів тощо.

Процес формування професійної ідентичності складається із сукупності професійних конструктів: професійного самовизначення; професійної придатності; вироблення 
професійно важливих якостей; професійної готовності; професійного розвитку; розробки професійного життєвого плану (Лукіянчук, 2010).

Отже, професійна ідентичність є частиною соціальної ідентичності особистості, що формується згідно з закономірностями соціальної ідентичності (самовизначення, вироблення поведінки в соціальній групі, позитивне ставлення до цієї групи, міжгрупові взаємини).

В процесі становлення професійної ідентичності особистість проходить ті ж етапи, що й при соціалізації: довіру, автономію, ініціативність, досягнення, ідентичність, інтимність, творчість, інтеграцію (Новик \& Мазур, 2019). Так, Л. Шнейдер виокремила кілька ступенів процесу становлення професійної ідентичності:

- невиражена (відсутність професійного досвіду і спілкування, чітких тактичних і стратегічних професійних цілей);

- виражена, але пасивна (набуття початкового досвіду, засвоєння початкового багажу знань, визначення своїх можливостей);

- активна (втілення в реальність обраних цілей, вироблення свого професійного стилю, спілкування);

- стійка (професійне самовдосконалення, вільне володіння професією, передача професійного досвіду, відчуття власної професійної значущості) (Шнейдер, 2004).

Водночас Л. Шнейдер джерелами формування професійної ідентичності вважає такі:

- об’єктивно існуючий освітньо-професійний компонент;

- суб'єктивна система очікувань і переваг, ідеальні образи професії;

- професійна самопрезентація та позитивне сприйняття себе як суб'єкта професійної діяльності;

- професійні норми (цінності) й атрибути; успішне освоєння правил і норм професійної діяльності (Шнейдер, 2004).

На думку А. Лукіянчука (Лукіянчук, 2010), професійна ідентичність - це динамічна система, яка формується у процесі професійної освіти та активного розвитку професійної компетентності та впливає на ціннісно-смислову сферу i удосконалення професійної майстерності майбутнього спеціаліста. Специфікою процесу формування професійної ідентичності $є$ те, що це практично неусвідомлюваний процес (Зеер, 1997). Тому так важливо в процесі професійної підготовки допомогти студентам знайти свої «особистісні смисли», власне місце в просторі обраної професії, де і як вони будуть працювати, чітко уявити очікуваний результат або продукт своєї професійної діяльності.

Отже, сучасна конструкція вищої професійної освіти повинна передбачати посилення його виховного аспекту, спрямованого на формування професійної ідентичності майбутніх випускників. 3 одного боку, це сприятиме подальшій успішній професійній діяльності випускників, а з іншого, дозволить вишам помітно підвищити якість навчання студентів заради майбутньої професії.

Важливо, щоб майбутні соціальні працівники мали сильну мотивацію сформувати власну ідентичність, як результат досягнення високого рівня внутрішньої психічної інтеграції та соціальної адаптації. Як тільки ідентичність сформована, то виникає прийняття себе, чітке самовизначення, а також прихильність до будь-якої професії. 3'являється внутрішня гармонія і прийняття своїх здібностей, можливостей і обмежень. Окреслюється більш реалістична концепція цілей (Райс \& Долджин, 2010: 334).

Т. Титаренко, слідом за Ф. Райсом, наголошує на тому, що особистість не буде змінюватися, якщо в неї немає внутрішньої інтенції. Якщо вона не бажає в своєму житті 
щось змінювати. Це свідчить про ії нестійку мотивацію, запозичену в когось, поверхневу. Особистісна гармонія, на думку вченої, характеризується максимальною відповідністю власному призначенню та запитам соціуму, різнобічними самовиявами на власну користь $\mathrm{i}$ користь суспільства. Задоволеність від повного розкриття власних здібностей і можливостей виникає, якщо людина знаходиться в гармонії на рівні індивідуальності (Титаренко, 2003).

Отож, формування різних компонентів ідентичності: фізичних, соціальних, професійних та ін. - складний процес, який залежить від мотивації особистості сформувати власну ідентичність, зокрема і професійну.

Аналіз літературних джерел дає підстави розглядати професійну ідентичність як динамічне утворення, феномен, що розвивається в процесі професійного становлення та сприяє самореалізації особистості, усвідомленню приналежності до певної професії й професійного співтовариства; це комплекс уявлень про себе як про професіонала, що забезпечує послідовне і оптимальне проходження всіх стадій професійного становлення (Азбель, 2004; Борисюк, 2010; Зеер, 1997; Кривоконь, 2002).

Як було зазначено вище, на сучасному етапі становлення вищої освіти проблема професійної ідентичності є досить актуальною, про що свідчить ії широке висвітлення у наукових джерелах. Тому створення умов для самостійного вибору практико-орієнтованих завдань, організація навчання на основі діяльнісного підходу сприяють розвитку професійної ідентичності, становленню внутрішньої мотивації професійної діяльності (Срмолаєва, 1998; Леонтьев, 2004; Лукіянчук, 2010; Новик \& Мазур, 2019).

Однак залишається недостатньо опрацьованою проблема набуття професійної ідентичності майбутніми соціальними працівниками. Зокрема такі іï важливі аспекти, як: набуття майбутніми соціальними працівниками ціннісно-смислових, мотиваційних утворень, пов'язаних із майбутньою професією; формування професійних планів, що зумовлюють зміни професійної самосвідомості майбутніх фахівців.

Мета дослідження: вивчення і формування професійної ідентичності майбутніх соціальних працівників у процесі підготовки у виші, що ініціює пошук нових орієнтирів освіти, цілей, можливостей. В контексті цієї проблеми поставлено завдання дослідити вплив освітнього контексту на динаміку становлення мотиваційних i ціннісно-смислових детермінант формування професійної ідентичності майбутніх фахівців соціальної роботи.

\section{Методи дослідження}

Емпіричне дослідження проводилося на базі Чернігівського національного технологічного університету в 2020 році. Учасниками дослідження стали студенти-магістри в кількості 20 осіб і студенти-бакалаври 1-го і 4-го курсів факультету соціальних технологій, оздоровлення та реабілітації в кількості 21 та 22 особи, відповідно. Як діагностичний інструментарій мотивації до професійної діяльності, використовувалася методика «Мотивація професійної діяльності» К. Замфір у модифікації А. Реана, яка дає можливість визначити певний мотиваційний комплекс особистості. Мотиваційний комплекс за К. Замфір $\epsilon$ зіставленням трьох видів мотивації: внутрішньої, зовнішньої позитивної та зовнішньої негативної. Вважається, що в оптимальному варіанті мотиваційного комплексу внутрішня мотивація має найбільше значення, порівняно з іншими компонентами, при тому, що зовнішня позитивна мотивація презентована також на високому рівні, але іiї показники вищі, ніж у внутрішній негативній мотивації. Таке розуміння зіставлення складових мотиваційного комплексу грунтується на уявленнях О. Леонтьєва про ієрархію мотивів: «... сенсоутворюючі 
мотиви завжди займають більш високе ієрархічне місце, навіть якщо вони не мають прямої афектогенності» (Леонтьєв, 2004: 154). Методика вимірює сім видів мотивів: задоволення від самого процесу і результату майбутньої професії, можливість найбільш повної самореалізації (внутрішня мотивація), грошовий заробіток, прагнення до просування по роботі, потреба в досягненні соціального престижу і поваги (зовнішня позитивна мотивація), прагнення уникнути критики, можливих покарань і неприємностей (зовнішня негативна мотивація).

Для оцінки рівня сформованості професійної ідентичності використовувалися методика вивчення статусів професійної ідентичності (Азбель, 2004). Дослідження статусів професійної ідентичності дозволяє глибше зануритися в розуміння сутності феномена професійної ідентичності, знайти зв'язки між різними статусами і компонентами професійної ідентичності. Статуси професійної ідентичності Дж. Марсіа та Е. Еріксон розуміють як стани формування ідентичності, що засвідчують проходження індивідуумом періоду прийняття рішення (кризи ідентичності), прийняття зобов'язання в ставленні щодо системи цінностей, власного майбутнього професійного шляху (Ericson, 1960; Marsia, 1980).

Спираючись на статусну модель Дж. Mapcia (Marsia, 1980), автори методики виокремили чотири статуси професійної ідентичності, як своєрідні сходинки, по яких піднімається людина у процесі професійного самовизначення:

- невизначена професійна ідентичність - це відсутність професійного вибору, чітких уявлень про кар'єру, людина не замислюється над актуальною проблемою;

- нав'язана професійна ідентичність - людина має сформовані уявлення про своє професійне майбутнє, однак вони нав'язані ззовні, а не є результатом самостійного вибору;

- мораторій (або криза вибору) професійної ідентичності, коли людина усвідомлює проблему вибору професії та знаходиться в процесі ії вирішення, однак найкращий варіант ще не визначений;

- сформована професійна ідентичність, яка свідчить про визначеність професійних планів і це є результатом усвідомленого самостійного рішення.

\section{Результати та дискусії}

Статистична обробка результатів проводилась за допомогою $\chi 2$ критерію.

Отримані результати досліджень (див. табл. 1) засвідчили наявність статистично достовірних відмінностей між групами студентів за показником «внутрішня мотивація». Випускники-бакалаври, на відміну від першокурсників і магістрів, мають більш сформовану внутрішню мотивацію до професійної діяльності. Тобто, у випускників-бакалаврів набагато краще сформована готовність до професійної діяльності, а спонукальні мотивами навчальнопрофесійної діяльності пов'язані із реалізацією власних здібностей, спілкування 3 професіоналами, творчого самовираження в професії. Отже, активізація й індивідуалізація навчально-професійної діяльності студентів, залучення їх до проєктних і дослідницьких завдань у межах навчального процесу сприяють розвитку активної суб'єктної позиції та внутрішньої професійної мотивації випускників-бакалаврів.

Вивчення статусів професійної ідентичності дозволяє констатувати наявність значущих відмінностей в групах за показником «мораторій професійної ідентичності». Дослідження засвідчило, що магістри, на противагу випускникам бакалаврату, на завершальному етапі навчання у виші переживають кризу професійної ідентичності, пов'язану з вибором альтернативних варіантів майбутньої професійної діяльності, й активно 
намагаються iї подолати за допомогою обгрунтованих і осмислених рішень про своє майбутне.

Таблиия 1

Особливості мотивації професійної діяльності (за методикою К. Замфір) і статусів професійної ідентичності (за методикою А. Азбель)

\begin{tabular}{|c|c|c|c|c|}
\hline показники & $\begin{array}{l}\text { Студенти- } \\
\text { бакалаври 1-го } \\
\text { курсу }\end{array}$ & $\begin{array}{l}\text { Студенти- } \\
\text { бакалаври 4-го } \\
\text { курсу }\end{array}$ & $\begin{array}{l}\text { Студенти- } \\
\text { магістри }\end{array}$ & $\chi^{2}$ \\
\hline \multicolumn{5}{|c|}{ Мотивація професійної діяльності } \\
\hline Внутрішня мотивація & 31,1 & 40,3 & 32,6 & $5,46^{*}$ \\
\hline $\begin{array}{l}\text { Зовнішня позитивна } \\
\text { мотивація }\end{array}$ & 37,3 & 34,2 & 38,1 & 1,65 \\
\hline $\begin{array}{l}\text { Зовнішня негативна } \\
\text { мотивація }\end{array}$ & 31,6 & 25,5 & 29,3 & 4,18 \\
\hline \multicolumn{5}{|c|}{ Статус професійної ідентичності } \\
\hline $\begin{array}{l}\text { Невизначена } \\
\text { професійна } \\
\text { ідентичність }\end{array}$ & 21,2 & 12,6 & 13,1 & 1,83 \\
\hline $\begin{array}{l}\text { Нав’язана професійна } \\
\text { ідентичність }\end{array}$ & 28,2 & 15,5 & 14,4 & 2,31 \\
\hline $\begin{array}{l}\text { Мораторій } \\
\text { професійної } \\
\text { ідентичності }\end{array}$ & 26,4 & 32,4 & 40,2 & $5,99 *$ \\
\hline $\begin{array}{l}\text { Сформована } \\
\text { професійна } \\
\text { ідентичність }\end{array}$ & 24,2 & 39,5 & 32,3 & $6,47^{*}$ \\
\hline
\end{tabular}

$* H_{\text {крит }}=5,33$ при $\boldsymbol{p} \leq 0,05$ і 9,35 при при $\boldsymbol{p} \leq 0,01$

Магістри набагато глибше розмірковують про можливі варіанти професійного розвитку, прагнуть якомога більше дізнатися про можливості свого працевлаштування. Зазвичай, більшість молодих людей після кризи вибору переходить до стану сформованої ідентичності. Цей емпіричний факт можна пояснити тим, що до закінчення навчання студенти-магістри більшою мірою, на противагу першокурсникам i випускникамбакалаврам, усвідомлюють варіативність перспектив свого професійного розвитку, прагнуть прийняти осмислене рішення 3 приводу професійного майбутнього, що демонструє суб'єктну позицію щодо власної професійної біографії.

Аналіз ідентифікаційних характеристик засвідчив, що навчально-професійна рольова позиція («студент соціальної роботи», «навчаюсь в університеті», «магістр соціальної роботи» «майбутній соціальний працівник») більшою мірою виявляється у магістрів, які демонструють досить високий рівень знань про себе як про майбутніх професіоналів. У них найбільшою мірою репрезентована професійна реальність, що може розглядатися як показник сформованої професійної ідентичності. 


\section{Висновки}

Отримані результати доводять, що рівень вищої освіти впливає на специфіку професійної ідентичності випускників. При описі свого «Я» в студентів-магістрів більш яскраво, порівняно з випускниками-бакалаврами, виявляється навчально-професійна позиція. Мораторій професійної ідентичності як показник ситуації, пов'язаної з активним пошуком оптимальних варіантів подальшого професійного розвитку, також більшою мірою характерний для вибірки студентів-магістрів. Випускники-бакалаври характеризуються переважанням внутрішньої мотивації професійної діяльності.

Динаміка становлення професійної ідентифікації в майбутніх соціальних працівників великою мірою зумовлюється їх особистісним розвитком. Проведене дослідження показало, що професійна ідентифікація майбутніх соціальних працівників формується в процесі навчання поетапно і пов'язана з розширенням у студентів уявлень про рольові аспекти професійної діяльності. Однак отримані результати демонструють неоднозначність впливу зміни спрямованості, цілей і змісту освіти, орієнтації на творчу ініціативу, самостійність студенів соціальної роботи. В студентів першого курсу, зазвичай, відбувається осмислення професійної ідентичності, коли на основі входження в нове соціальне і професійне середовище зовнішня студентська ідентичність трансформується в внутрішньо прийняту, усвідомлену, емоційно забарвлену характеристику. У випускників-бакалаврів і магістрів відбувається формування нових цілей і перспектив професійного розвитку, переосмислення й уточнення різних варіантів професійно-творчого саморозвитку, працевлаштування й побудови професійної кар'єри. Тому підвищення конкурентоспроможності і мобільності майбутніх фахівців соціальної роботи обумовлює необхідність цілеспрямованого підвищення рівня професійної ідентичності студентів в період вишівської підготовки. Також важливо, щоб майбутні соціальні працівники мали сильну мотивацію сформувати власну ідентичність, як результат досягнення високого рівня внутрішньої психічної інтеграції та соціальної адаптації. Як тільки ідентичність сформована, виникає прийняття себе, чітке самовизначення, а також прихильність до будь-якої професії. Виникає внутрішня гармонія $\mathrm{i}$ прийняття своїх здібностей, можливостей і обмежень. 3'являється реалістичніша концепція цілей. Адже сформована професійна ідентичність $є$ показником успішного освоєння компетенцій і готовності до їх реалізації у професійній діяльності, а також слугує надійною системою координат для осмислення як професійного, так і особистісного розвитку студента.

Перспективи подальших досліджень вбачаємо в розробці психорозвивальних програм 3 формування професійної ідентичності майбутніх соціальних працівників.

\section{Література}

1. Азбель, А.А. (2004). Особенности формирования статусов профессиональной идентичности. (Дисс канд. психол. наук). Санкт-Петербург.

2. Борисюк, А. (2010). Професійна ідентичність як складова самосвідомості особистості. Актуальні проблеми психологї̈: Психологія навчання. Генетична психологія. Медична психологія: 3б. наук. праџь, Х(17), 45-55.

3. Ермолаева, Е.П. (1998). Профессиональная идентичность как комплексная характеристика соответствия субъекта и деятельности. Психологическое обозрение, 2, 3540.

4. Зеер, Э.Ф. (1997). Кризисы профессионального становления личности. Психологический журнал, 18(6), 35-44.

5. Кривоконь, Н.І. (2002). Соціально-психологічні чинники професійної самоідентифікації фахівців системи захисту населення. (Автореф. дис. канд. психол. наук). Київ.

6. Леонтьев, А.Н. (2004). Деятельность. Сознание. Личность. Москва : Смысл. 
7. Лукіянчук, А.М. (2010). Проблема ідентифікації у професійному становленні студентів вищого навчального закладу I-ІІ рівнів акредитації педагогічного профілю. Київ.

8. Новик, Л.М, \& Мазур, Т.В. (2019). Особистісні чинники суб’єктної активності майбутнього фахівця соціальної роботи. Науковий часопис НПУ імені М.П. Драгоманова. Серія 12. Психологічні науки, 8(53), 57-65.

Режим доступу: http://enpuir.npu.edu.ua/handle/123456789/28044?mode=full

9. Райс, Ф., \& Долджин, К. (2010). Психология подросткового и юномеского возраста (12-е изд., с. 334-335). Санкт-Петербург : Питер.

10. Титаренко, Т. (2003) Життєвий світ особистості у межах $i$ за межами буденності. Київ : Либідь.

11. Шнейдер, Л.Б. (2004). Профессиональная идентичность: теория, эксперимент, тренінг : учеб. пособие. Москва-Воронеж : МПСИ : МОДЭК.

12. Ericson, E.H. (1960). The problem of ego identity. In M.R. Stein et al. (Eds.) Identity and anxiety: Survival of the person in mass society. Glencoe : The Free Press.

13. Marsia, J.E. (1980). Identity in adolescence. In J. Adelson (Ed.) Handbook of adolescent psychology (p.159-187). New York : John Wiley.

\section{References}

1. Azbel, A.A. (2004). Osoblyvosti formuvannya statusiv profesiynoyi identychnosti [Features of the formation of the status of professional identity]. Candidate's thesis. St. Petersburg. [in Russian].

2. Borysyuk, A. (2010). Profesiyna identichnist yak skladovoho samosvidomosti osobystosti [Professional identity as a component of personal self-awareness]. Aktualni problemy psykholohiyi: Psykholohiya navchannya. Henetychna psykholohiya. Medychna psykholohiya: Zb. nauk. Prats - Current problems of psychology: Psychology of learning. Genetic psychology. Medical Psychology: Coll. Science. Works, $(X) 17,45-55$ [in Ukrainian].

3. Yermolayeva, E.P. (1998). Professionalnaya identichnost kak kompleksnaya kharakteristika sootvetstviya subyekta i deyatelnosti [Professional identity as a complex characteristic of the correspondence between the subject and the activity]. Psikhologicheskoye obozreniye Psychological Review, 2, 35-40. [in Russian].

4. Zeer, E.F. (1997). Krizisy professionalnogo stanovleniya lichnosti [Crises of the professional development of the personality]. Psikhologicheskiy zhurnal - Psychological journal. 18(6), 3544 [in Russian].

5. Kryvokon, N.I. (2002). Sotsialno-psykholohichni chynnyky profesiynoyi samoidentifikatsiyi fakhivtsiv systemy zakhystu naselennya [Socio-psychological factors of professional selfidentification of specialists of the population protection system]. Extendet abstract of Candidate's thesis. Kyiv [in Ukrainian].

6. Leontyev, A.N. (2004). Deyatelnost. Soznaniye. Lichnost. [Activity. Consciousness. Personality]. Moskow : Smysl. [in Russian].

7. Lukiyanchuk, A.M. (2010). Problema identifikatsiyi u profesiynomu stanovlenni studentiv vyshchoho navchal'noho zakladu I-II rivniv akredytatsiyi pedahohichnoho profilyu [The problem of identification in the professional development of students of higher educational institution of I-II levels of accreditation of pedagogical profile]. Kyiv [in Ukrainian].

8. Novyk, L.M., \& Mazur, T.V. (2019) Osobistisni Chynnyk subyektnoyi aktivnosti maybutnoho fakhivtsya sotsialnoyi roboty [Personal factors of subjective activity of the future social work specialist]. Naukovyy chasopys NPU imeni M.P. Drahomanova. Seriya 12. Psykholohichni nauky - Scientific Journal of National Pedagogical Dragomanov University. Series 12. Psychological Sciences, 8(53), 57-65.

Retrieved from: http://enpuir.npu.edu.ua/handle/123456789/28044?mode=full [in Ukrainian].

9. Rays, F., \& Doldzhyn, K. (2010). Psykholohyya podrostkovoho y yunosheskoho vozrasta [Psychology of adolescence and adolescence] (12nd ed., pp. 334-335), Sankt-Peterburh : Piter [in Russian].

10. Tytarenko, T. (2003) Zhyttyevyy svit osobystosti u mezhakh i za mezhamy budennosti [The life world of the individual within and outside of everyday life]. Kyiv : Lybid [in Ukrainian].

11. Shneyder, L.B. (2004). Professionalnaya identichnost: teoriya, eksperiment, trening : ucheb. posobiye. [Professional identity: theory, experiment, training : textbook]. Moscow-Voronezh : MPSI : MODEK [in Ukrainian]. 
12. Ericson, E.H. (1960). The problem of ego identity. In M.R. Stein et al. (Eds.) Identity and anxiety: Survival of the person in mass society. Glencoe : The Free Press.

13. Marsia, J.E. (1980). Identity in adolescence. In J. Adelson (Ed.) Handbook of adolescent psychology (p.159-187). New York : John Wiley.

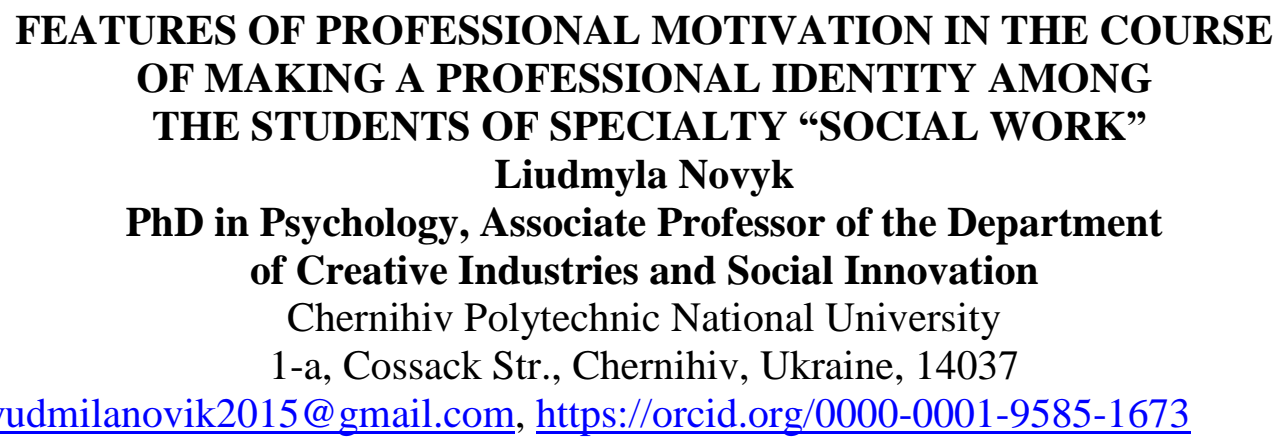

\author{
Tamara Mazur \\ PhD in Psychology, Associate Professor of the Department \\ of Philosophy and Social Sciences \\ Chernihiv Polytechnic National University \\ 1-a, Cossack Str., Chernihiv, Ukraine, 14037 \\ offerlund@gmail.com, http://orcid.org: 0000-0002-0609-6416
}

\begin{abstract}
The article considers the problem of forming the professional identity of the future social work specialist, which, according to the authors, can significantly increase the motivation of students to acquire a profession. The data of educational motivation research testify direct influence of higher education level on specificity of professional identity among the graduates of "Social work" specialty. The dynamics of professional identification of future social workers is largely determined by their personal development. Master's students have a more pronounced academic and professional identification than bachelor's students that are characterized by the predominance of intrinsic motivation for professional activity.

The research purpose is to study and form the professional identity of future social workers in the process of university training, which initiates the search for new landmarks in education, goals and opportunities. In the context of this problem, we set the task to investigate the influence of the educational context on the dynamics of the formation of motivational and value-semantic determinants of the professional identity formation among future social workers. The results obtained prove that the level of higher education affects the specifics of the professional identity of graduates. The first year students actually make a sense of professional identity, and having entered a new social and professional environment, the external student identity turns into an internally accepted, conscious, emotionally colored characteristic. BA and MA graduates are shaping new goals and prospects for professional development, rethinking and refining various options for professional and creative self-development, employment and building a professional career. Therefore, increasing the competitiveness and mobility of future professionals in social work necessitates a purposeful increase in the level of professional identity of the students during university training.
\end{abstract}

Keywords: professional identity, professional motivation, self-realization, self-determination, professional development, identity. 